\title{
Land Value Capture and Tax Increment Financing: Overview and Considerations for Sustainable Urban Investment
}

\author{
Simon Hugh Huston ${ }^{1 *}$, Ebraheim Lahbash ${ }^{2}$ \\ ${ }_{1}^{1}$ The Royal Agricultural University, Stroud Road, GL76JS Cirencester, UNITED KINGDOM \\ 2 Skyline Real Estate, UNITED ARAB EMIRATES
}

*Corresponding Author: simon.huston@rau.ac.uk

Citation: Huston, S. H. and Lahbash, E. (2018). Land Value Capture and Tax Increment Financing: Overview and Considerations for Sustainable Urban Investment. European Journal of Sustainable Development Research, 2(3), 34. https://doi.org/10.20897/ejosdr/2666

Published: July 17, 2018

\begin{abstract}
The paper reviews the notion of Land Value Capture (LVC), its advantages and disadvantages and relevance to for urban growth management. LVC encompasses a wide range of mechanisms, applied in very diverse contexts to monetize 'windfall' gains, accruing to landowners because of growth, infrastructure or placemaking projects. Despite widespread conviction that a proportion of these 'unearned increments' should somehow be harvested for the wider public good, contention, legal and pragmatic challenges remain. As policy makers confront population pressures, transport needs and inequality, LVC can help bridge infrastructure funding gaps, accelerate housing provision and temper polarisation. Betterment taxes, Tax Increment Finance (TIF) or participatory instruments like land readjustment can target 'planning gains' capitalized into land and property values near stations, historic monuments or upgraded precincts. As well as flagging instrument diversity and variable contexts, the literature suggests LVC mechanisms work best in a joined-up policy context. Ironically, spatial LVC schemes like TIF are most likely to fail when the regeneration need is most acute. In America, inadequate governance, scrutiny or auditing undermined schemes to fund transport or improve the public realm. In Europe LVC exists in a variety of modalities but three European examples, suggests it remains underutilized. London megaprojects, UK regional housing schemes and French sprawl, illustrate that policy makers have yet to adequately capture unearned increments.
\end{abstract}

Keywords: land value capture, TIF, LVT, project funding, developer obligations, betterment, unearned increment, windfall gains, planning gain

\section{INTRODUCTION: THE PROBLEM}

It is not the fortunes which are earned, but those which are unearned, that it is for the public good to place under limitation. Mill (1848; V, II V2.14)

The distribution of land, its change of use or intensification are almost invariably contentious (Owens and Cowell, 2011). Ever since Pericles (495-429 BCE) regenerated Athens or Nero (37-68 AD) constructed his Domus Aurea (Golden House), urban development has caused controversy (Perkins, 1956; Ball, 2003; Pomeroy et al., 2004). In modern times, sustainability challenges are immense. Kuanga et al. (2016) estimate that over the decade 1990-2010 China's built area increased by 42,300 km² (over 25 x London's 2011 built area). Not only has this land use intensification undermined Chinese food security but Harrison (2017) alleges that its beneficiaries bribed local officials to secure cheap land leases. Inevitably, land use alteration or intensification generates winners, who profit from value uplift; and losers who are disturbed or dispossessed so community consultation is vital (Sanyal and 


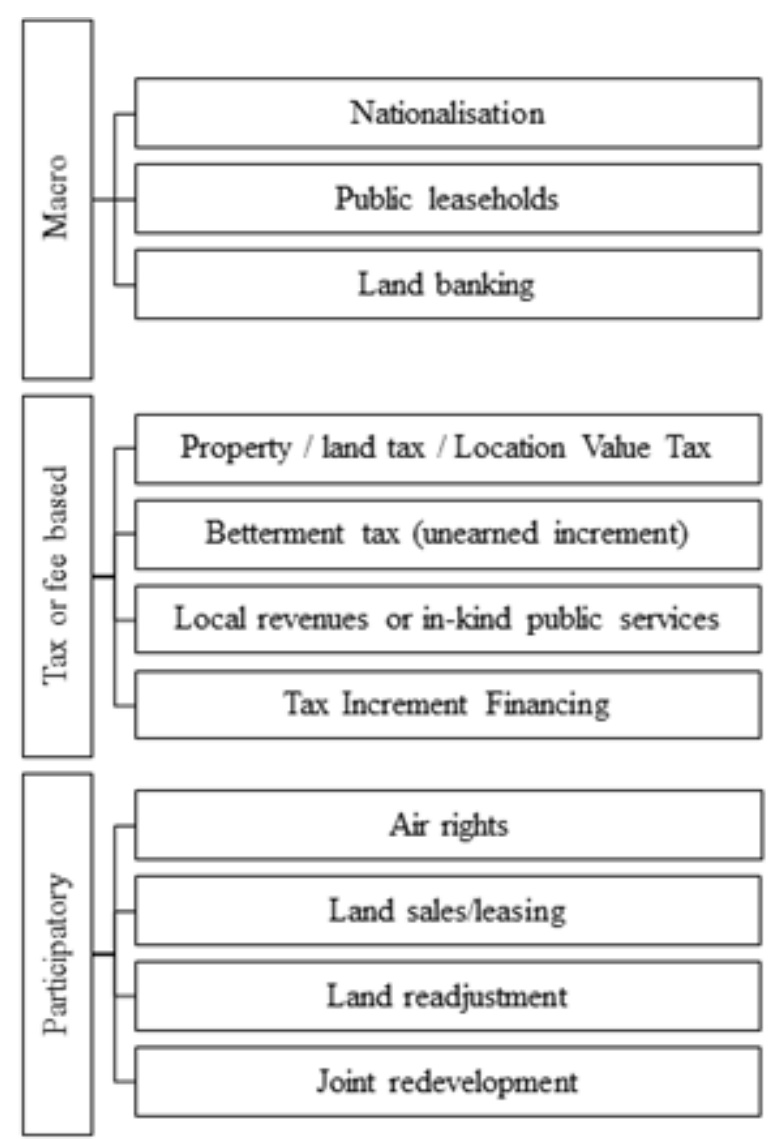

Figure 1. Overview of Land Value Capture policy instruments in Macro, Tax or Participatory vehicles (Source: Author, adapted from Alterman 2012; Gerber et al., 2018; World Bank 2015)

Deuskar 2012; Sharma and Newman 2018). Even the OECD (2015), acknowledges that the construction and real estate sectors are prone to mismanagement, corruption and distributive injustices. Harrison (ibid. 2017) claims that land and property tax injustice corrodes the legitimacy of current UK fiscal regime. For Mirrlees (2010), the solution is to switch the tax burden from income toward land, property and other assets.

Advocates of Land Value Capture (LVC) claim the policy instrument can curtail the theft of public patrimony, increase housing supply, curtail sprawl and attenuate planning disputes. LVC is not new. In Islam, it is called Kharaj (Lewis, 2002; LVTC, 2018). Ricardo (1817) advocated LVC to capture what he called 'non-functional' rents, unearned increments or, in general, excessive returns to capital (Piketty, 2013). As its name suggests, LVC impounds a proportion of the windfall gains accruing to landlords due to general economic conditions or population growth. LVC also targets betterment gain induced by infrastructure or the relaxation of planning constraints (Mill, 1848; George, 1881; Doherty, 2004; Dye and England, 2011; Alterman, 2012; Hendricks et al., 2017; Rebelo, 2017; Gerber et al., 2018). For Rebelo (2017:392), LVC supports 'the economic and financial stability of urban development'. Despite public conviction that a proportion of these unearned increments should somehow be harvested for the wider public good, policy, pragmatic and legal challenges remain in diverse global contexts (Andelson, 2000). Figure 1 illustrates the gamut of possible LVC implementation mechanisms. LVC operates at the national level or it recoups some land value or any increments attributed to public interventions via taxes, services or participatory contributions. LVC mechanisms include taxation (levied on land value or on development value uplift from a baseline), fees or sharing project benefits. At the micro-spatial scale, 'unearned increments' are captured either fiscally (taxes, fees, exactions) or via mandatory on-site improvements (participation or fees). Notice within the tax vehicles, the distinction between Location Value Tax (LVT) and betterment taxes. Unlike property taxes, LVT disregards the value of buildings or improvements to real estate. Land Value Capture ('LVC') generally targets landowners but mechanisms such as Tax Increment Financing (TIF) widen the transport or infrastructure beneficiary net (Greenbaum and Landers 2014; Medda and Modelewska 2013). Within the participatory vehicles, Alterman (2012) considers land readjustment the 'sleeping beauty' or a sophisticated and malleable mechanism to harvest surplus gains. Alterman (2012: 767) suggested studying LVC issues in the Britain because 'vicissitudes with various types of betterment capture policies make it the world's most distinctive laboratory'. The LVC research here investigates a couple of UK cases, US and the Australian experiences and French LVC issues. 


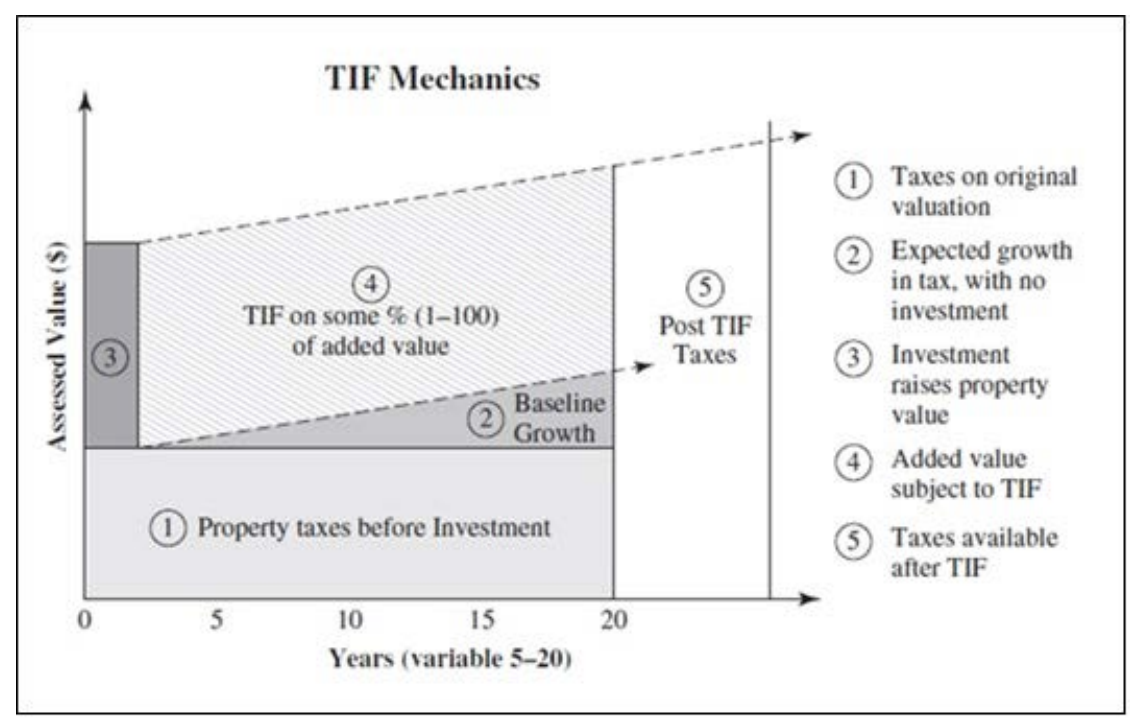

Figure 2. TIF mechanics (Source: Lefcoe 2011: 457)

In the UK, Council Tax is locally and regionally regressive (Muellbauer, 2005). Vested interests contaminate planning obligation deliberative arenas to inflate Threshold Land Values and cut developer contributions (McAllister, 2017). Property buyers pay Stamp Duty Land Tax (SDLT) on land or property over thresholds of $£ 125,000$ (residential property) or $£ 150,000$ (for non-residential land). In Australia, states levy land taxes with a range of exemptions and varying thresholds (Wilkinson, 2017). In America, TIF originated in the 1950s in California with policy initiatives to match federal urban blight remediation dollars with local contributions. TIF de-risks projects but other measures like tax breaks or subsidies enhance its effectiveness. TIF enables local governments to issue bonds to finance for infrastructure / improvements. The bonds are underpinned by hypothecated future property tax increases. In the designated project area, future tax streams are 'ring fenced'. The TIF funding mechanism involves, first, the legal designation of the scheme and its spatial taxation zone. Second, the prospective property value uplifts are estimated and then consequential incremental municipal tax revenues are capitalised to secure mortgage finance. A TIF effectively strengthens future property tax revenues covenants to enable local authorities to borrow money for necessary (sustainable) infrastructure projects. The downside risk is that projected property value increases fail to materialise - either because the project fails or the macro-cyclical climate alters. For Carroll (2008), TIF provides useful rehabilitation tool. For her, the long-term benefits of revitalization and property inflation outweigh tax revenue restrictions. Figure 2 below illustrates the TIF mechanism.

Be that as it may, successful TIF implementation imposes three conditions. First, baseline analysis should not only demonstrate blight or a local need (betterment or affordable housing) but also business rates and property prices in the TIF area ('redline area'). To test whether regeneration via a TIF is really necessary, invokes a 'but for' test (Greenhalgh et al., 2012). Collected financial and valuation baseline data underpins prudent modelling of estimated incremental TIF income (i.e. excluding 'displacements' or establishments likely to relocate to avoid tax hikes). As new facts emerge, computations are updated. The second condition for successful TIF schemes is enabling (or TIF authorising) legislation to clarify contractual terms and circumscribe the spatial boundaries of the TIF. Finally, TIF success presupposes central and local government involvement both in approval and in management. Whilst many municipalities resent intrusive oversight, Squires and Hutchison (2014) investigation of Californian schemes found Regional Development Agency support critical both to independently vet projects and to properly manage tax receipts earmarked for affordable housing or sustainable regeneration.

\section{Advantages}

LVC comes in many forms. The arguments for LVC expansion on economic, strategic, fiscal and equity grounds seem impelling. Economically, such taxes improve resource allocation. In California during the 1940s-50s and again in the 80-90s, TIF financed redevelopment helped reverse inner city decay. Recently, the UK Government considered introducing some form of LVT to incentivise home construction (Wilson et al., 2017). Privatising the social housing stock has led to a massive surge in sub-standard Private Rented Sector accommodation (rogue landlords), who are effectively subsidised to the tune of over twenty six billion by the public purse (Shelter, 2017). LVT could help solve the UK's affordable housing crisis but it also mitigates sprawl. Strategically and financially, LVC provides a pragmatic funding solution for regeneration or resilience and carbon mitigating infrastructure (Granoff et al., 2016). In the UK, TfL and GLA (2017) advocate the TIF mechanism to bridge the infrastructure funding gap. 
In the past, general taxation has funded the gap (...) [but] as the funding requirement grows, without alternative funding sources, there is no obvious way of paying for major network. upgrades and extensions, other than increasing the burden on general taxation. Land value capture (LVC) is one such alternative funding source. (TfL and GLA, 2017: p6)

Research by Savills and KPMP for London's mayor estimated that investment of $£ 36 \mathrm{bn}$ on eight Transport for London projects, including Crossrail 2, the Bakerloo line extension and the Dockland Light Railway extension, could produce land value uplifts of about $£ 87 \mathrm{bn}$ (TfL and GLA, 2017: p7). It seems right that homeowners who benefit from such infrastructure via shorter commutes and property uplift should help fund it. Caroll (2008) found that within TIF district public service enhancement is capitalized into business property value. Man and Rosentraub (1998) found transport infrastructure inflated property values in Indiana by $11 \%$. In Australia, McIntosh et al. (2015) found that LVC schemes can raise significant funding for public transportation or Transit Oriented Developments (TODs). However, homeowners in the catchment often complain that the tax is unfair or excessive compared to benefits. To counter this charge, the California Constitution Article (CVI, s16; Proposition 13, 1978) capped property tax rates at one percent (plus enough to repay bonded indebtedness). Valuations could only be increased following a change in ownership or new construction except for an annual across-the-board inflation adjustment of $2 \%$ - but only if inflation equalled or exceeded that level. Even this tightening though failed to stop complaints and, in 1993, further legislation restricted Californian TIF programmes to affordable housing or areas which met strict 'blighted' criteria. In 2011, California Governor Jerry Brown ended TIF for redevelopment and handed over TIF revenue management to external bodies. Notwithstanding the mixed US picture, Squires and Hutchison (2014) point out that TIF schemes played an important role in financing affordable housing.

In England, there is some appetite for UK TIF (Wilson et al., 2017) but still disagreement on management aspects particularly among local authorities ('LA's'). TIFs were ushered in by the Local Government Finance Act 2012. Whilst LA's are enthusiastic about TIF unlocking regeneration, they have reservations about TIF in blighted areas because, even with uplift in values, Business Rates are unlikely to recoup project costs. Councils also demand assurance that TIF offers value for money compared to 'in-house' government financing. Notwithstanding, any regeneration projects must also overcome usual planning contentions about surrounding impacts. Notable Scottish TIF projects include:

- Glasgow City Region City Deal will see $f_{1} 1.13$ billion infrastructure spend to 2035, hoping to leverage \&3bn private investment.

- Edinburgh Waterfront is a mixed residential/commercial development in Leith. Council invested $£_{8} 84 \mathrm{~m}$.

- Ravenscraig in North Lanarkshire aims to regenerate its blighted steelworks. More than $f 200 \mathrm{~m}$ has been invested, including $£, 70 \mathrm{~m}$ for a college $£, 32 \mathrm{~m}$ for a sports facility but hopes for another $£ 425 \mathrm{~m}$ from Wilson Bowden and other private investors.

- Buchanan Galleries where Glasgow City Council invested $f_{80} \mathrm{~m}$ to redevelop the Buchanan Quarter, hoping to leverage $f_{310 \mathrm{~m}}$ from Land Securities and Henderson Global Investors.

\section{Disadvantages}

In her empirical international review, Alterman (2012) found 'messy' negotiated LVC imposts or planning obligations have proliferated whist elegant direct-capture approaches faltered mainly because these indirect LVC tools provide a pragmatic mechanisms to fund public services. However, this really indicates policy failing. Even with so-called indirect capture instruments, landowners and developers face an impost lottery and the risk of a local political backlash or legal challenges. For end-users, the betterment quid pro quo is also unpredictable.

In recent times, government and media attention has focused on TIF but this territorial LVC instrument has significant disadvantages, including loss of control, risk shifting, cycles and the deprivation paradox. In terms of control, TIF critics point out that that local governments effectively lose control over some property tax income. Once an area is declared a redevelopment project area, the share of property taxes that goes to schools and other local agencies is frozen. All expost property taxes growth in the designated zone flows back to the redevelopment agency. Money for schools, water or sewage etc. upgrades is 'siphoned off' for redevelopment projects.

TIF detractors argue that TIF developers shift risk onto the public sector. Factors increasing contention between private and public risk sharing include wrangling over spatial decay of beneficial spillovers, ill-considered institutional structures or lack of legal clarity around roles and responsibilities. Any injections of public equity investment into a scheme should bring more effective control. In California, concerns over lack of TIF control and risk shifting resulted in two bills in June 2011 which curtailed TIF redevelopment agencies. Before Proposition 13 in California tax assessors routinely adjusted tax assessed values to current fair market value. In housing booms, homeowners were burdened with huge property tax hikes. A tax revolt was sparked by property tax increases in 1975-77, with house prices climbing 28\% in 1977 alone. In such a frothy market, Proposition 13 cut ballooning property tax bills and ended TIF agencies. It also outlined a TIF dissolution process. However, TIF agencies who funded schools were reprieved. Redevelopment agencies and cities sued, claiming these bills were unconstitutional. The court decided California could quash TIF redevelopment agencies but without any exemptions. The third 


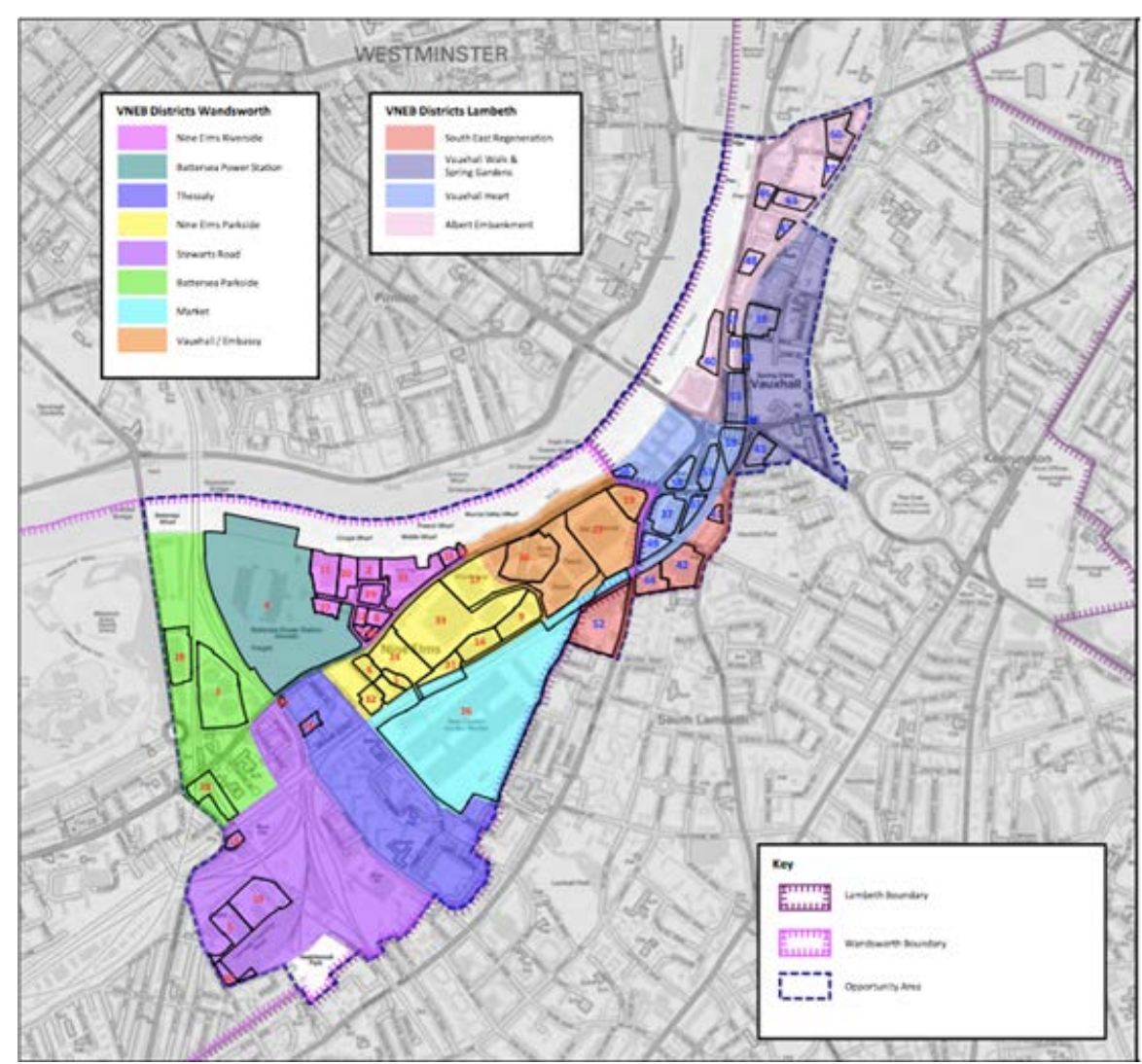

Figure 3. Nine elms development boundaries (Wandsworth council, 2017)

disadvantage of LVC schemes like TIF relates to financial or real estate market assumptions and forecasting uncertainties for baseline residual land valuations, fair values or estimates of worth. In London and Manchester, contention around urban land values has bedevilled feasibility assessments or viability" appraisals for affordable housing (Cocksedge, 2018). If development has been mooted for many years but not formalised in a scheme, baseline assessments become questionable. Often when project knowledge becomes public, markets react and capitalise growth. Other cyclical concerns involve estimates of yields or discount rates, anticipated market conditions, take up by anchor tenants and projected commercial rents (Jadevicius and Huston, 2017). Finally, according to Lefcoe (2011: 443), 'TIF is an ineffectual tool for assisting most seriously blighted areas' essentially because investors are unwilling to throw good money after bad. This deprivation paradox really is a pretty serious indictment of spatially-based LVC instruments since where schemes are most acutely needed to address spatial injustice and attenuate polarisation, they struggle with funding.

\section{CASE STUDIES}

Having reviewed a range of literature, the research reflects on LVC issues and opportunities by briefly considering three European case studies in UK and France.

\section{UK London (Nine Elms)}

Inequality and fragmentation in the UK housing market manifests most grotesquely in London where in recent times megaprojects like Nine Elms, Kings Cross and Olympic Park and Crossrail have transformed the capital (Edwards, 2009). The $f_{13}$ billion (US $\$ 15.9$ billion) Nine Elms regeneration project of 227 hectares on the South Bank of the River Thames is illustrated in Figure 3.

The regeneration scheme extends from Lambeth Bridge in the north, to Chelsea Bridge in the south, covering the Albert Embankment, Vauxhall and a large slice of north Battersea. Westminster lies directly opposite on the north bank of the Thames. It is by far the largest regeneration zone in central London and has transformed the last remaining industrial stretch of the South Bank. Curiously, in Nine Elms no Tax Increment Financing mechanism captured land value uplift although the Section 106 funding and Community Infrastructure Levy did recoup some of the uplift for the community. In fact, landowners partially funded initial works with off-plan sales but major extensions to the underground effectively subsidised revitalisation. The Northern Line Extension (NLE) project extended the underground from Kennington to Battersea and built two stations at Nine Elms and at 


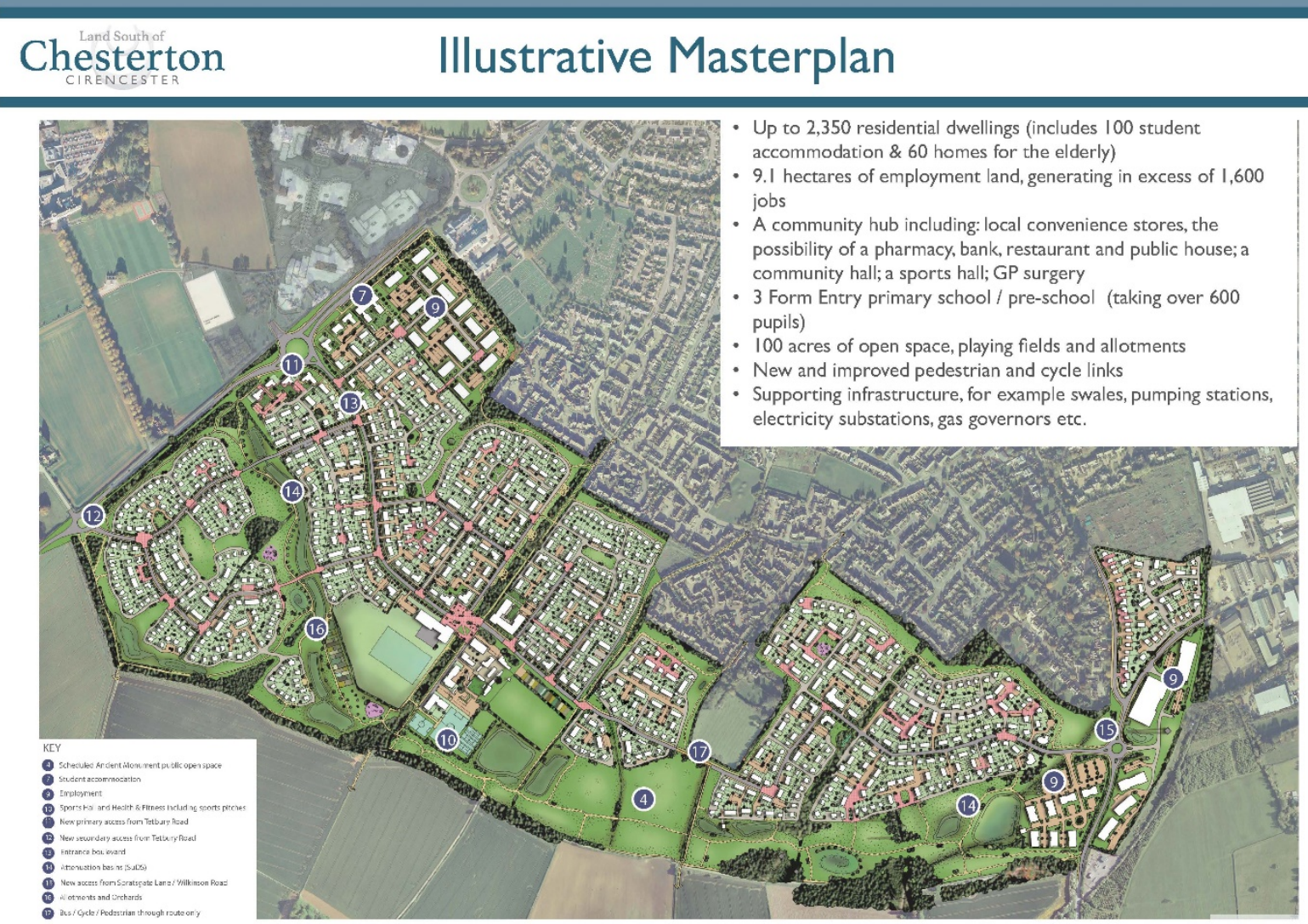

Figure 4. Chesterton Masterplan 2015 (Source: Bathurst Development Ltd)

Battersea. In contrast to the Kings Cross regeneration scheme, despite its vision, Nine Elms provides limited pubic spinoffs in terms of cycle ways and green space and effectively remains a privileged enclave (GLA, 2012).

\section{UK Region: Cirencester Chesterton Development}

Regional UK settlements are under intense pressure to increase housing supply but with very limited supportive infrastructure funding. Cirencester in the Cotswolds, one hour west of Oxford, is a typical example. Its recent Draft Local Plan, has approved a strategic site in Chesterton south of the town to provide most of the Cotswold District council (CDC) thirty year supply of housing (CDC, 2018). The beneficiaries of CDC's housing supply centralisation are the site landowner and wealthy homeowners in outlying villages who not only avoid congestion and other externalities but are also likely to surreptitiously reap unearned increments in housing value. So rather than being sustainable, the plan is quite the opposite from a social perspective. Interestingly, the voting pattern of local councillors on the Plan reflects these vested interests. Cirencester Town's concerns about the inappropriate scale of the scheme and lack of connective infrastructure were largely ignored despite public relations claims to involve the community in shaping the future (Jessel, 2018).

\section{France: Regional Fragmentation}

Like many countries, France faces a challenge to spread the impacts of globalisation and logistic concentration to its regions. The challenge is most acute in rural departments like the Lot and Corrèze, particularly at the interfaces of such regional administrations where weak strategy and lack of coordination compound the inherent tension between real estate growth and the need for sustainable territorial management. An excellent milieu to study the phenomenon of globally- induced real estate sprawl is the settlement of Beaulieu sur Dordogne which spills over towards Bretenoux, Biars, Glanes and St. Céré. Over the past twenty years since 1998, the number of dwellings in Cere-Dordogne river valley conurbation area has risen dramatically, despite relatively static population (INSEE, 2018). Two mechanisms drive the process of anthropogenic intensification; first is the expansion of industrial and logistics operations around Biars sur Cère and the presences of a large multinational food conglomerate such as Andros. Second is the spread of second and retirement properties by French or overseas investors. Figure 5 illustrates how the workers or retirees cluster in locales with views over heritage artefacts like the Château de Castelneau. 


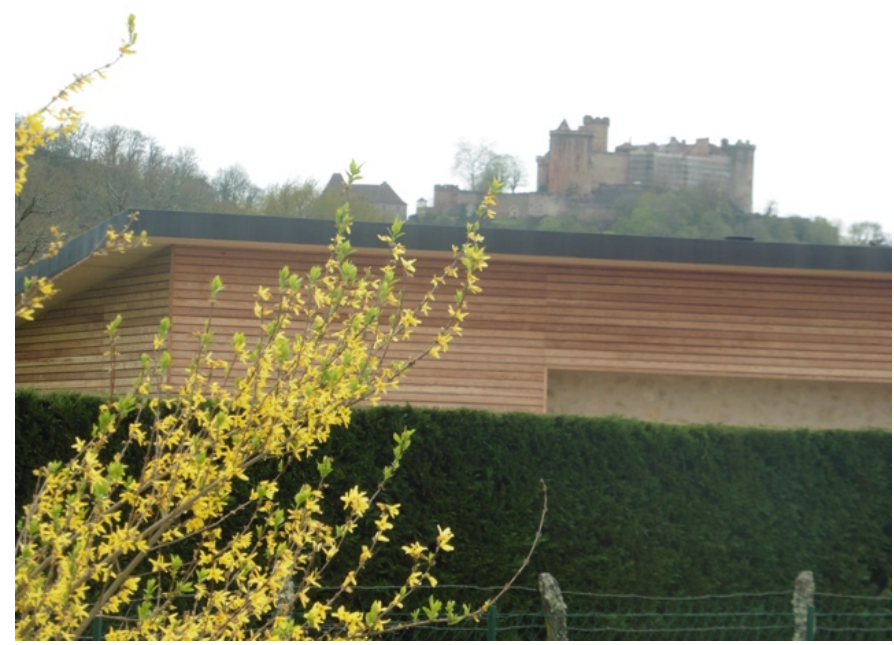

Figure 5. New housing sprawl in Cere-Dordogne river valley conurbation 2018 (Source: Author)

\section{DISCUSSION}

The literature review and the three case studies provides a rounded, if somewhat empirically limited, review of LVC. LVC can be implemented via national vehicles or more spatially-targeted with either imposts on values, betterment charges, fees or participation in project gains. Many local municipalities face tight budget pressures and TIF schemes present them with an innovative place-making, redevelopment or infrastructure funding tool to improve project feasibility, cut government outlays and spread risk. However, the TIF conundrum is that it generally works best for attractive projects in locales which have been overlooked but not in seriously blighted areas with significant social problems. Target projects need careful vetting to ensure suburban shopping malls which encourage sprawl and displace trade from city centres are excluded. To help ensure successful TIF implementation, careful consideration needs to be given to TIF project institutional structure (TIF Corporations) and public and private project collaboration. To catalyse useful projects, government land can be gifted or the legislative powers of resumption exercised. In terms of institutional collaboration, local planning authorities must develop credible bundled infrastructure and services plans so that the risk/reward credentials of TIF bond issues become acceptable to banks, pension funds and overseas investors.

Regarding TIF schemes, specific considerations include:

- Sound institutional framework for territorial development. Spatial planning coordination provides legal clarity, champions the public interest and vets TIF sites/projects properly to exclude commercial development without public good merit

- Regional planning bodies and TIF corporations require talented, motivated and ethical administrative staff

- Extensive local consultation is required to ensure TIF projects do not drain property tax revenues from schools or other important local commitments.

- Independent oversight to vet and financial scrutiny to audit projects

- Seriously blighted locales with compromised prospects require alternative funding streams and interagency support to de-risk projects and catalyse regeneration

\section{CONCLUSION}

Sustainable urban development calls for significant investment in public transport, walkable precincts, cycle ways and carbon-reducing infrastructure generally to enhance or to protect / remediate ecologically sensitive areas. One way to fund the green infrastructure gap is Land Value Capture which comes in many guises. As well a diversity of mechanisms, the literature suggests that Land Value Capture has advantages and disadvantages but needs institutional territorial and spatial planning support. Context variability precludes a standardised application across projects, locales and jurisdictions. Whilst TIF can finance infrastructure for upmarket malls, gated housing or other commercially lucrative but fossil-fuel dependent projects it fails without subsidies where it is most needed to overcome serious blight, deprivation or isolation. In such depleted locales, non-spatial (general revenue) imposts or borrowings must supplement territorially raised LVC finance for infrastructure or regeneration. Generalised LVC instruments like a land tax could help redress unbalanced tax systems and attenuate wealth inequality. Fiscal 
policy reform aside, LVC also requires sound territorial policy and robust institutions. LVC operational supports involve spatial data and technologies, comprehensive land registration, inter-governmental collaboration, expert scrutiny, authentic consultation with local residents, regular financial viability reviews and independent audits.

\section{REFERENCES}

Andelson, R. V. (2000), Land-V alue Taxation around the World, 3rd Ed., Oxford, Blackwell.

Alterman, R. (2012). Land use regulations and property values: the windfalls capture idea revisited. pp. 755-786. The Oxford handbook of urban economics and planning. Brooks, N., Donaghy, K., \& Knaap, G. J. (Eds.). Oxford, Oxford University Press.

Ball, L. F. (2003). The Domus Aurea and the Roman architectural revolution. Cambridge University Press. https://doi.org/10.1017/CBO9780511666551

Carroll, D. (2008). Tax Increment Financing and property value: an examination of business property using panel data. Urban Affaires Review, 43(4), 520-552. https://doi.org/10.1177/1078087407308516

CDC (2018). Emerging Local Plan. Available at: http://www.cotswold.gov.uk/residents/planningbuilding/planning-policy/emerging-local-plan/local-plan-examination/local-plan-core-documents/mainlocal-plan-submission/ (Accessed April 2018).

Cocksedge, C. (2018). Housing crisis: 15,000 new Manchester homes and not a single one 'affordable'. Guardian online $5^{\text {th }}$ March 2018. Available at: https://www.theguardian.com/cities/2018/mar/05/british-citiesdevelopers-affordable-housing-manchester-sheffield (Accessed April 2018).

Doherty, M. (2004). Funding public transport development through land value capture programs. Institute for Sustainable Futures, 30.

Dye, R. and England, R. (2011). Land Value Taxation: Theory, Evidence, and Practice. Cambridge, MA: Lincoln Institute of Land.

Edwards, M. (2009). King's Cross: renaissance for whom? Urban Design, urban renaissance and British Cities, (Ed: Punter, J.), London, Routledge.

Gerber, J. D., Hartmann, T. and Hengstermann, A. (Eds.). (2018). Instruments of Land Policy: Dealing with Scarcity of Land. Routledge.

George, H. (1879). Progress and Poverty. New York, Applegate.

GLA. (2012). Vauxball Nine Elms Battersea Opportunity Area Planning Framework. Greater London Authority. Available at: file://filestore/staff/shuston/Downloads/VNEB_OAPF_2012_0.pdf (Accessed April 2018).

Granoff, I., Hogarth, J. R. and Miller, A. (2016). Nested barriers to low-carbon infrastructure investment. Nature Climate Change, 6, 1065-1071. https://doi.org/10.1038/nclimate3142

Greenhalgh, P., Furness, H. and Hall, A. (2012). Time for TIF? The prospects for the introduction of Tax Increment Financing in the UK from a local authority perspective. Journal of Urban Regeneration \& Renewal, 5(4), 367-380.

Greenbaum, R. T. and Landers, J. (2014). The tiff Over TIF: a review of the literature examining the effectiveness of the Tax Increment Financing. National Tax Journal, 67(3), 655-674. https://doi.org/10.17310/ntj.2014.3.06

Harrison, F. (2017). Systemic Integrity: the Australian model. In F. Harrison (Ed.), Debt Death and Deadweight: the Acts of Parliament. Available at: https://landresearchtrust.org/ (Accessed April 2018).

Hendricks, A., Kalbro, T., Llorente, M., Vilmin, T. and Weitkamp, A. (2017). Public Value Capture of increasing property values-what are 'unearned increments'? Land ownership and land use development: the integration of past, present, and future in spatial planning and land Management policies, in Erwin Hepperle (Ed). Zürich, vdf Hochschulverlag AG an der ETH Zürich.

INSEE. (2018). Institut national de la statistique et des études économiques. Paris, available at https: / / www.insee.fr/fr/statistiques?debut=0\&categorie=3 (accessed April 2018).

Jadevicius, A. and Huston, S. (2017). How long is UK property cycle? Journal of Property Investment \& Finance, 35(4), 410-426. https://doi.org/10.1108/JPIF-10-2016-0083

Jessel, E. (2018). JTP gets green light for peer's controversial Cirencester scheme. The Architects' Journal $5^{\text {th }}$ April 2018.

Kuanga, W., Liua, J., Dongb, J., Chia, W. and Zhangc, C. (2016). The rapid and massive urban and industrial land expansions in China between 1990 and 2010: A CLUD-based analysis of their trajectories, patterns, and drivers. Landscape and Urban Planning, 145, 21-33. https://doi.org/10.1016/j.landurbplan.2015.10.001

LVTC. (2018). Land Value Tax Campaign. What is LVT? Accessed at: http://www.landvaluetax.org/what-is-lvt/ (Accessed April 2018).

Lefcoe, G. (2011). Competing for the next hundred million Americans: the uses and abuses of Tax Increment Financing. Urban Lanyer, 43, 427-482.

Lewis, B. (2002). The Arabs in History. Oxford: Oxford University Press. 
Man, J. Y. and Rosentraub, M. S. (1998). Tax increment financing: municipal adoption and effects on property value growth. Public Finance Review, 26(6), 523-547. https://doi.org/10.1177/109114219802600601

McAllister, P. (2017). The calculative turn in land value capture: Lessons from the English Planning System. Land Use Policy, 63, 122-129. https:// doi.org/10.1016/j.landusepol.2017.01.002

McIntosh, J., Trubka, R. and Newman, P. (2015). Tax Increment Financing framework for integrated transit and urban renewal projects in car-dependent cities. Urban Policy and Research, 33(1), 37-60. https://doi.org/10.1080/08111146.2014.968246

Medda, F. and Modelewska, M. (2013). Land value capture as a funding source for urban investment: the Warsaw metro system. London, University College Qaser Lab.

Mill, J. S. (1848). Principles of political economy with some of their applications to social philosophy, $7^{\text {th }}$ edition, 1909. London; Longmans, Green and Co.

Mirrlees, J. A. (2010). Dimensions of tax design: the Mirrlees review. Oxford University Press.

Morris, I. (2005). The growth of Greek cities in the first millennium BC, Stanford University. Available at: https://www.princeton.edu/ pswpc/pdfs/morris/120509.pdf (Accessed July 2016).

Muellbauer, J. (2005). Property taxation and the economy. In D. Maxwell and A. Vigor (eds.), Land Value Tax: worth the transition? Oxford, IPPR and University of Oxford.

OECD. (2015). Towards a framework for the governance of infrastructure. OECD Public Governance and Territorial Development Directorate Public Governance Committee September 2015.

Owens, S. and Cowell, R. (2011). Land and limits: interpreting sustainability in the planning process. 2nd Edition, Abingdon, Routledge.

Perkins, J. W. (1956). Nero's Golden House. Antiquity, 30(120), 209-219. https://doi.org/10.1017/S0003598X00026843

Piketty, T. (2013). Le Capital au XXIe siècle. Paris, Éditions du Seuil.

Pomeroy, S. B., Burstein, S. M., Donlan, W., Roberts, J. T. and Tandy, D. W. (2004). A brief history of ancient Greece: Politics, society, and culture. Oxford University Press.

Rebelo, E. (2017). Land betterment revisited: a methodology for territorial plans. Land Use Policy, 69, 392-407. https://doi.org/10.1016/j.landusepol.2017.08.015

Ricardo, D. (1817). On the principles of political economy and taxation. 3rd edition, 1821. London: John Murray.

Sharma, R. and Newman, P. (2018). Can land value capture make PPP's competitive in fares? A Mumbai case study. Transport Policy, 64, 123-131. https:// doi.org/10.1016/j.tranpol.2018.02.002

Sanyal, B. and Deuskar, C. (2012). A Better way to grow? Town planning schemes as a hybrid land readjustment process in Ahmedabad, India. In V alue Capture and Land Policies, edited by Ingram G. and Y. Hong, 149-82. Cambridge, MA: Lincoln Institute of Land Policy.

Shelter. (2015). Building the homes we need: a programme for the 2015 government. Shelter. Available at: http://www.shelter.org.uk/_data/assets/pdf_file/0019/802270/Building_the_homes_we_need__a_programme_for_the_2015_government.pdf (Accessed April 2018).

Squires, G. and Hutchison, N. (2014). The death and life of Tax Increment Financing (TIF) redevelopment lessons in affordable housing and implementation. Property Management, 32(5), 368-377. https://doi.org/10.1108/PM07-2013-0037

TfL and GLA (2017). Land Value Capture: final report. Transport for London and Greater London Authority (2017), involving research by Savills and KPMG. Available at: https://www.london.gov.uk/sites/default/files/land_value_capture_report_transport_for_london.pdf (Accessed 15 January 2018).

Wilkinson, S. J., Sayce, S. L. and Christensen, P. H. (2015). Developing property sustainably. Abingdon, Routledge.

Wilson, W., Barton, C. and Smith, L. (2017). Tackling the Under-supply of Housing in England. Commons Library Briefing Paper, 2017, London.

World Bank. (2015). Financing transit-oriented development with land values: adapting land value capture in developing countries. Authors: Suzuki, H., Murakami, J., Hong, Y. and B. Tamayose. Washington, DC. World Bank. 